\title{
FURTHER DEVELOPMENTS ON THE WAVE OVERTOPPING SIMULATOR
}

\author{
Jentsje W. van der Meer ${ }^{1}$, Gosse Jan Steendam², Govertine de Raat ${ }^{3}$ and \\ Patricia Bernardini ${ }^{4}$
}

\begin{abstract}
The Wave Overtopping Simulator was developed in 2006 and destructive tests on dikes have been performed in February and March of 2007 and 2008. The tests show the behaviour of various inner slopes of dikes, embankments or levees under simulation of wave overtopping, up to a mean overtopping discharge of $125 \mathrm{l} / \mathrm{s}$ per $\mathrm{m}$. This paper focuses on the improvements of the Wave Overtopping Simulator after the 2007 tests and summarizes the results of the tests performed early 2008, ending with preliminary conclusions.
\end{abstract}

\section{INTRODUCTION}

The process of wave overtopping on a dike, levee, seawall or embankment has been subject of a huge amount of research and the overall conclusion is that the hydraulic part of wave overtopping on a dike is well-defined, see the Overtopping Manual (2007). In contrast, the erosive impact of wave overtopping on dikes, embankments or levees is not known well, mainly due to the fact that research on this topic can not be performed on a small scale, as it is practically impossible to scale clay and grass down properly. Hence, in order to establish the resistance or strength of a dike for wave overtopping, destructive field tests are required. This has led to the idea of the Wave Overtopping Simulator. The basic idea is that only the overtopping part of the waves need to be simulated, see Figure 1.

The simulator was developed and designed early 2006 within the ComCoast project, see Van der Meer et al. (2006 and 2007) The simulator consists of a mobile box (adjustable in height) to store water. The maximum capacity is now $5.5 \mathrm{~m}^{3}$ per m width ( $22 \mathrm{~m}^{3}$ for the $4 \mathrm{~m}$ wide simulator) and a discharge of $75 \mathrm{l} / \mathrm{s}$ per $\mathrm{m}$ is possible. This box is continuously filled with a predefined discharge $\mathrm{q}$ and emptied at specific times through a butterfly valve and it simulates the overtopping tongue of a wave at the crest and inner slope of a dike. When the box is filled with a required volume, $\mathrm{V}$, the valve is opened and the water is released on a transition section that leads to the crest of the dike. It is released in

\footnotetext{
${ }^{1}$ Van der Meer Consulting b.v., P.O. Box 423, 8440 AK, Heerenveen, The Netherlands; jm@vandermeerconsulting.nl

${ }^{2}$ Infram, P.O. Box 16, 8316 ZG, Marknesse, The Netherlands

${ }^{3}$ Ministry of Transport, Public Works and Water Management, Centre for Water Management, P.O. Box 17, 8200 AA, Lelystad, The Netherlands

${ }^{4}$ Ministry of Transport, Public Works and Water Management, Directorate-General for Public Works and Water Management, P.O. Box 5044, 2600 GA, Delft, The Netherlands
} 
such a way that flow velocity, turbulence and thickness of the water tongue correspond with characteristics that can be expected.
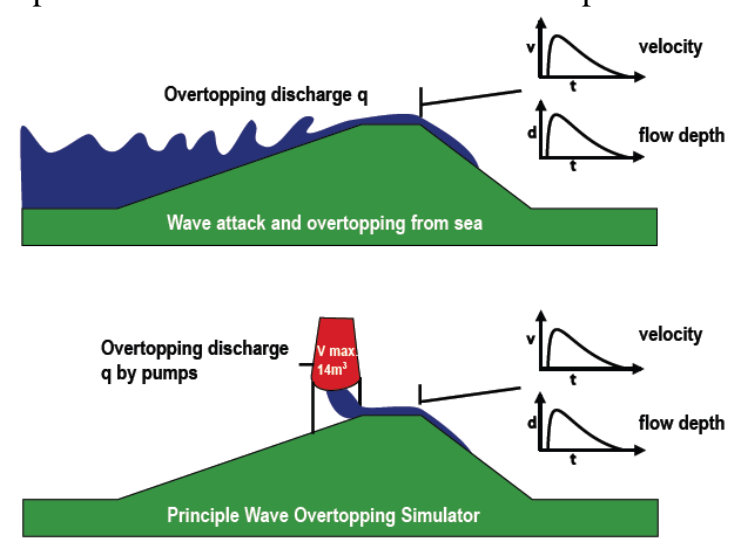

Figure 1. Principle of wave overtopping simulator

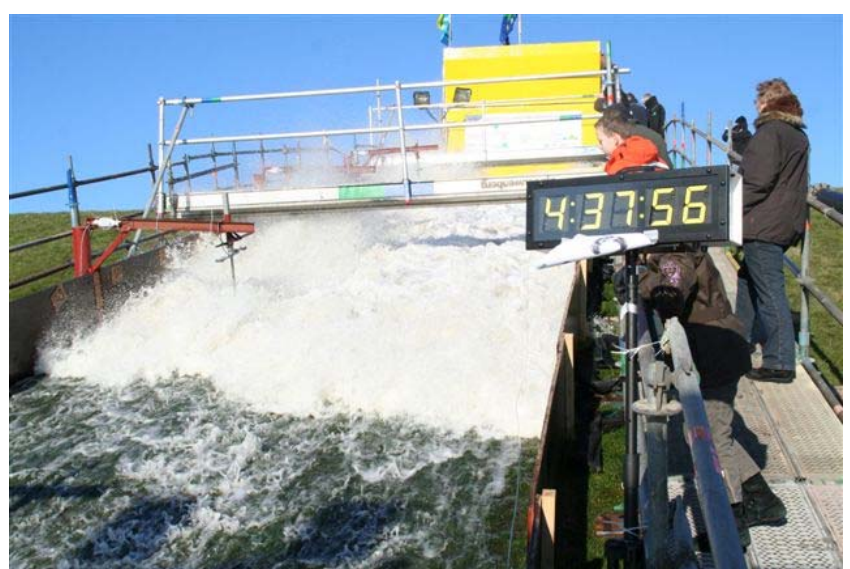

Figure 2. Wave Overtopping Simulator at a dike, releasing $22 \mathrm{~m}^{3}$ in a few seconds

Field tests on real dikes have been carried out in 2007 and 2008. Figure 2 shows the working of the simulator at the crest of a dike, releasing $22 \mathrm{~m}^{3}$ of water in a few seconds. The Wave Overtopping Simulator in action and the test results of the resistance of the first tested dike have been described by Van der Meer (2007) and Akkerman et al. (2007-1 and 2007-2). The wave overtopping simulator worked very well and also the erosion strength of the inner slope of the dike was surprisingly large, showing no damage for overtopping discharges up to $50 \mathrm{l} / \mathrm{s}$ per m width.

Specific dike sections, tested in spring 2008 along the Frysian Waddensea, have been maintained in different ways during the past 15 years. Different vegetation has been developed on each section with different root systems of this vegetation. The purpose of the tests was to investigate the influence of 
management and maintenance of the grass on erosion strength. Directly after that dikes in the south west of the Netherlands have been tested with bad coverage of grass, steeper inner slope, a number of holes of moles and also reinforced systems (as open asphalt concrete) have been tested. Various of these tested dike sections failed for 50 or $75 \mathrm{l} / \mathrm{s}$ per $\mathrm{m}$. The tests at the Frysian Waddensea have been described by Steendam et al. (2008).

A summary report on all the testing, with many pictures of damages and with preliminary conclusions, has been described by Van der Meer (2008).

This paper focuses on details of wave overtopping at sea and river dikes, on improvements of the simulator after the first tests in 2007 and on preliminary conclusions with respect to the test results.

\section{WAVE OVERTOPPING AT SEA AND RIVER DIKES}

Mean overtopping discharges and distributions of overtopping waves can be calculated by methods given in the Overtopping Manual (2007). The mean overtopping discharge is an input parameter for the overtopping tests: the required overtopping discharge is pumped into the Wave Overtopping Simulator. It depends, however, on actual storm conditions and dike geometry how many waves will overtop the dike and how large the overtopping volumes will be. In order to make a correct simulation, it is necessary to set these boundary conditions.

\section{Sea Dikes}

Sea dikes were tested in 2007 and 2008. For the time being it was assumed that these dikes have a 1:4 outer slope with a smooth revetment (grass or other protection). The significant wave height at the toe of the structure was assumed to be $2 \mathrm{~m}$, with a wave steepness (with peak period) of 0.04 . These are more or less average conditions for Dutch sea dikes. The final assumption was a storm duration of 2 hours. With these data it is possible to calculate distributions of overtopping volumes for each required mean overtopping discharge. Some characteristic values have been summarized in Table 1 and distributions of overtopping volumes are shown in Figure 3.

\begin{tabular}{|c|c|c|c|c|c|c|c|c|}
\hline \multicolumn{9}{|c|}{$\begin{array}{l}\text { Characteristic values depending on mean overtopping discharge. } \\
\text { Background: } \mathrm{H}_{\mathrm{s}}=2 \mathrm{~m} ; \mathrm{s}_{\mathrm{op}}=0.04 \text {, outer slope } 1: 4 \text { and storm duration } 2 \text { hours }\end{array}$} \\
\hline $\begin{array}{l}\text { Mean overtopping } \\
\text { discharge (I/s per } \mathrm{m} \text { ) }\end{array}$ & 0,1 & 1 & 10 & 30 & 50 & 75 & 100 & 125 \\
\hline Crest freeboard $(\mathrm{m})$ & 5.06 & 3.84 & 2.61 & 2.03 & 1.76 & 1.54 & 1.39 & 1.27 \\
\hline $\begin{array}{l}\text { Percentage of over- } \\
\text { topping waves (\%) }\end{array}$ & 0.2 & 2.7 & 18.9 & 36,6 & 47 & 56 & 62 & 68 \\
\hline $\begin{array}{l}\text { Number of overtop- } \\
\text { ping waves }\end{array}$ & 3 & 42 & 289 & 561 & 720 & 858 & 956 & 1034 \\
\hline $\begin{array}{l}\text { Maximum overtop- } \\
\text { ping volume }(1 / \mathrm{m})\end{array}$ & 400 & 835 & 2110 & 3790 & 5180 & 6750 & 8250 & 9680 \\
\hline
\end{tabular}




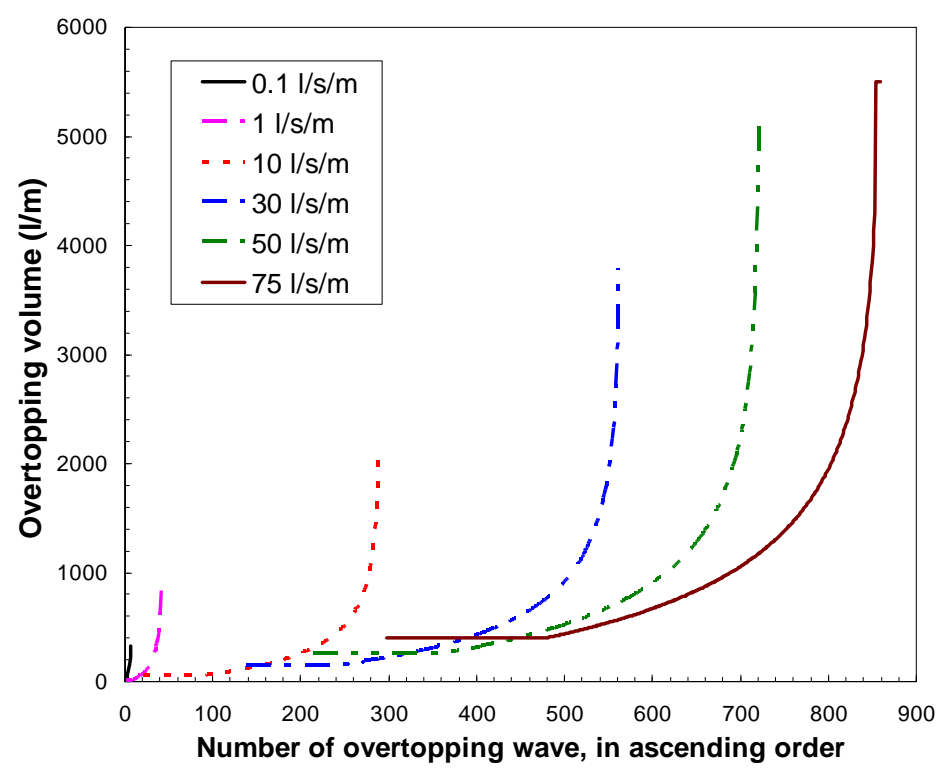

Figure 3. Distribution of overtopping waves for sea dikes and various mean overtopping discharges, as simulated by the Wave Overtopping Simulator. Background: see Table 1.

Most dikes in the Netherlands have been designed for $1 \mathrm{l} / \mathrm{s}$ per $\mathrm{m}$. The water level has to raise $2.3 \mathrm{~m}$ more to come to a mean overtopping discharge of $75 \mathrm{l} / \mathrm{s}$ per $\mathrm{m}$, see Table 1 . The number of overtopping waves increases then from 42 to 858 on a total of about 1500 incident waves. The maximum overtopping volume increases from $835 \mathrm{l} / \mathrm{m}$ to $6750 \mathrm{l} / \mathrm{m}$ (but the Wave Overtopping Simulator is limited to $5500 \mathrm{l} / \mathrm{m}$ ).

The smallest overtopping waves are not simulated. This is because the valves in the Simulator need some time to open and close. The minimum time required before the next wave can be simulated is about $5 \mathrm{~s}$. With a mean discharge (actually the pumping discharge) of $50 \mathrm{l} / \mathrm{s}$ per $\mathrm{m}$ it can be calculated that in $5 \mathrm{~s}$ the smallest wave to be simulated is $250 \mathrm{l}$ per $\mathrm{m}$. The total volume of the smaller overtopping waves in the theoretical overtopping distribution is simulated with a fixed number of waves with the minimum volume, giving the same total volume. These are the horizontal lines in Figure 3.

\section{River Dikes}

The loading on river dikes is different than on sea dikes (or dikes along large lakes). A sea dike has to withstand a storm surge with associated large wave attack. Often the crest height is much higher than the expected storm surge, as it has to cope with the large waves which will run-up and possibly overtop. A river dike in principle has to withstand a large river discharge, and therefore, a high water level. But often this will be without large wave attack. 
And if a storm occurs during a large river discharge, fetches will be short and waves will be small. Often the crest level of a river dike is not much higher than the design water level.

Overtopping on a river dike means in essence overtopping with small wave attack. Still the same average overtopping discharges can be reached, from say $0.1 \mathrm{l} / \mathrm{s}$ per $\mathrm{m}$ to $125 \mathrm{l} / \mathrm{s}$ per $\mathrm{m}$. Wave heights at river dikes are often only $1 \mathrm{~m}$ or even smaller. To compare with sea dikes a wave height of $0.75 \mathrm{~m}$ has been taken for overtopping discharges till $10 \mathrm{l} / \mathrm{s}$ per $\mathrm{m}$ and a wave height of $1 \mathrm{~m}$ for the larger discharges. Again a wave steepness of $\mathrm{s}_{\mathrm{op}}=0.04$ is taken (steepness with wind waves), a storm duration of 2 hours and an outer slope of 1:3, which is a little steeper than used at sea dikes. Table 2 gives a similar table as Table 1 , but now for river dikes. The distributions of overtopping volumes have been given in Figure 4.

\begin{tabular}{|c|c|c|c|c|c|c|c|c|}
\hline \multicolumn{9}{|c|}{$\begin{array}{l}\text { Characteristic values depending on mean overtopping discharge. } \\
\text { Background: } H_{s}=0.75 \mathrm{~m} \text { for } 0.1 ; 1 \text { and } 10 \mathrm{l} / \mathrm{s} \text { per } \mathrm{m} \text { and } H_{s}=1 \mathrm{~m} \text { for other; } \\
S_{\text {op }}=0.04 \text {, outer slope } 1: 3 \text { and storm duration } 2 \text { hours }\end{array}$} \\
\hline $\begin{array}{l}\text { Mean overtopping } \\
\text { discharge (I/s per m) }\end{array}$ & 0,1 & 1 & 10 & 30 & 50 & 75 & 100 & 125 \\
\hline Crest freeboard (m) & 1.91 & 1.36 & 0.82 & 0.89 & 0.73 & 0.6 & 0.51 & 0.44 \\
\hline $\begin{array}{l}\text { Percentage of over- } \\
\text { topping waves (\%) }\end{array}$ & 1.1 & 10.1 & 44 & 58 & 69 & 78 & 84 & 88 \\
\hline $\begin{array}{l}\text { Number of overtop- } \\
\text { ping waves }\end{array}$ & 32 & 295 & 1263 & 1450 & 1733 & 1952 & 2091 & 2188 \\
\hline $\begin{array}{l}\text { Maximum overtop- } \\
\text { ping volume }(1 / \mathrm{m})\end{array}$ & 98 & 208 & 659 & 1765 & 2543 & 3460 & 4317 & 5185 \\
\hline
\end{tabular}

Figures 3 and 4 and Tables 1 and 2 show that there are many more overtopping waves for river dikes than for sea dikes, with the same overtopping discharge. Consequently, the maximum overtopping volumes are smaller for river dikes. This is about half of the maximum overtopping volumes for the larger overtopping discharges. Even a discharge of $125 \mathrm{l} / \mathrm{s}$ per $\mathrm{m}$ can be simulated by the Wave Overtopping Simulator, as the maximum volume is 5185 $\mathrm{l} / \mathrm{m}$, where the capacity of the Simulator is $5500 \mathrm{l} / \mathrm{m}$.

Another important difference is that for river dikes the crest freeboard becomes very small. For $30 \mathrm{l} / \mathrm{s}$ per $\mathrm{m}$ it is $0.89 \mathrm{~m}$ and if the water level in the river rises half a meter the overtopping discharge becomes more than $125 \mathrm{l} / \mathrm{s}$ per $\mathrm{m}$ for a crest freeboard smaller than half a meter. The differences become even larger if compared for small overtopping discharges. The sea dike in Table 1 needs a crest freeboard of almost $4 \mathrm{~m}$ to limit the wave overtopping to $1 \mathrm{l} / \mathrm{s}$ per $\mathrm{m}$. For the river dike in Table 2 this is just over $1 \mathrm{~m}$.

The main conclusion is that large wave heights give large overtopping volumes in a small number of waves, where small wave heights give many more 
overtopping waves, but smaller overtopping volumes. All for the same discharge.

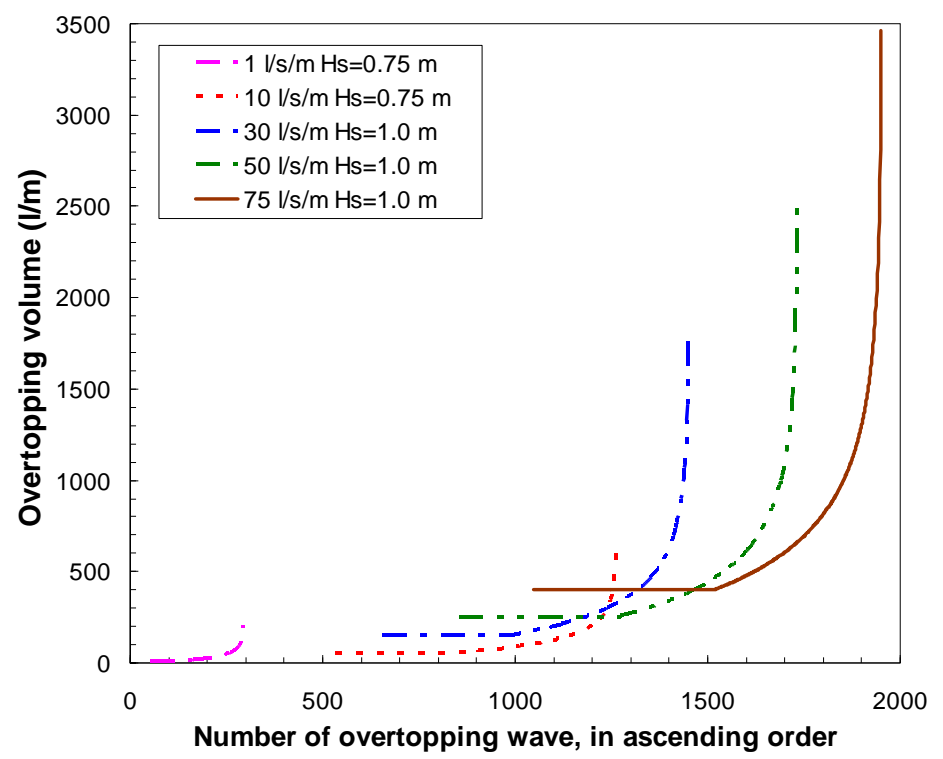

Figure 4. Distribution of overtopping waves for river dikes and various mean overtopping discharges, as simulated by the Wave Overtopping Simulator. Background: see Table 2.

\section{IMPROVEMENTS OF THE WAVE OVERTOPPING SIMULATOR}

The Wave Overtopping Simulator was originally designed for a maximum average overtopping discharge of $30 \mathrm{l} / \mathrm{s}$ per $\mathrm{m}$. This gave, with an assumed wave height of $\mathrm{H}_{\mathrm{s}}=2 \mathrm{~m}$, a box volume of $3.5 \mathrm{~m}^{3}$ per m width $\left(14 \mathrm{~m}^{3}\right.$ over the full width of $4 \mathrm{~m}$ ). As described by Van der Meer et al. (2007), already during the first test in 2007 it became clear that (good) grass covers did not show damage for this overtopping discharge. For those tests the discharge was increased to a maximum of $50 \mathrm{l} / \mathrm{s}$ per $\mathrm{m}$, although a few overtopping volumes of more than $3.5 \mathrm{~m}^{3}$ could not be simulated, due to the limited size of the box.

In 2007 it was decided to enlarge the volume of the Simulator. An extra box of $8 \mathrm{~m}^{3}$, or $2 \mathrm{~m}^{3}$ per $\mathrm{m}$, was placed on top of the existing Simulator, see Figure 5. The total volume of the Simulator became $22 \mathrm{~m}^{3}$ or $5.5 \mathrm{~m}^{3}$ per m width. With this size it is possible to simulate an average overtopping discharge of $75 \mathrm{l} / \mathrm{s}$ per $\mathrm{m}$ (assuming a wave height of $2 \mathrm{~m}$ ), see also Figure 3. If it is accepted that a small number of very large overtopping volumes can not be generated, even an overtopping discharge of $125 \mathrm{l} / \mathrm{s}$ per $\mathrm{m}$ can be simulated. This has been done for two tests on artificial overtopping resistant systems, open stone asphalt and elastocoast. For these tests it was required to increase the pump capacity by two extra centrifugal pumps, as the main frequency controlled plunge pump had 
only a capacity of $1200 \mathrm{~m}^{3}$ per hour, which is just enough for $75 \mathrm{l} / \mathrm{s}$ per m discharge.

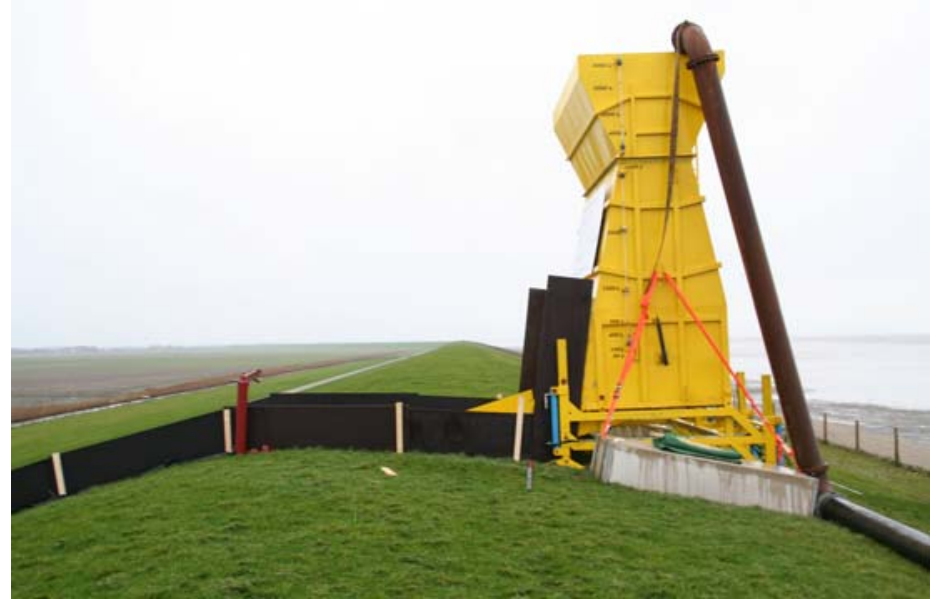

Figure 5. The modified Wave Overtopping Simulator with an extra box on top to increase the total volume to $22 \mathrm{~m}^{3}$, and placed on a hydraulically adjustable platform.

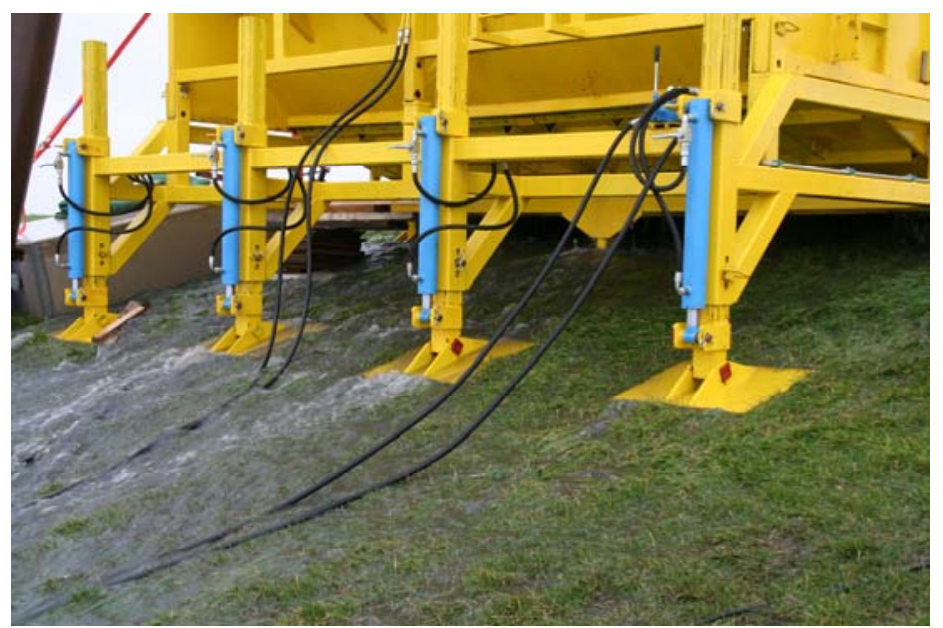

Figure 6. Rear side of the hydraulically adjustable platform which supports the Wave Overtopping Simulator. Some water is leaking to the seaside.

Another improvement made was the design and construction of a foundation or platform for the Simulator. This platform has 4 adjustable legs on the rear side and 3 on the front side. Each leg has a hydraulic cylinder which makes it easy to put the Simulator in an upright position. This can also be done after some time if some uneven settlement has occurred. The platform made the positioning of the Simulator on the right location on the dike easier, as well as the positioning in an upright lining. The footings of the legs were also enlarged 
in order to avoid too much settlement into the dike body. This was necessary as the volume of the Simulator and therefore the total full weight was increased to more than 25 ton.

The simulation of overtopping waves occurred by opening and closing of the butterfly valve in the Simulator at dedicated times. Till now this was done manually by a joystick, see Van der Meer et al. (2007). The first tests in 2007 were performed with a number of fixed overtopping volumes, giving a discontinuous distribution of overtopping volumes which followed more or less the theoretical distribution. The tests in 2008 were performed with simulation of the theoretical distributions, as in Figure 3, except for the very small overtopping volumes (see the description of Figure 3).

\section{MEASUREMENTS OF FRONT VELOCITIES}

In 2007 velocities of overtopping water were measured by an electromagnetic velocity meter, EMS. In Van der Meer et al. (2007) it was clearly concluded that the measurements were hampered by the highly turbulent and aerated overtopping flow. Actually, real velocities could not be recorded at that time and the EMS was not the right instrument to use.

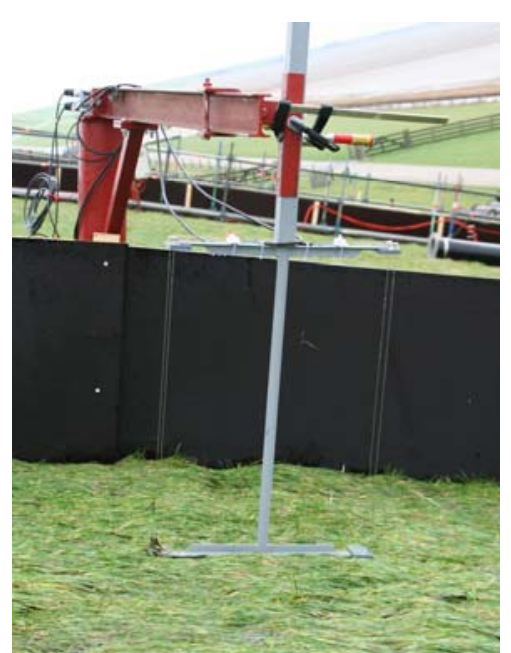

In 2008 it was decided to record the front velocity at 5 locations on the inner slope by pairs of thin wire gauges, see Figure 7 . The distance between the gauges was $0.50 \mathrm{~m}$. In between the gauges was a mounting rod. During the tests it appeared that flowing water was split by this mounting rod and gave a very unstable signal for the second wire gauge. Actually, this system did not work correctly in this set-up.

As five pairs of wire gauges were placed on the inner slope, the alternative was to connect the first gauges of each pair on this slope. The distance between

Figure 7. A pair of thin wire gauges to these gauges was $2.5 \mathrm{~m}$. measure front velocities

The data processing took a lot of time as every event had to be coupled to the simulated overtopping volume and small overtopping volumes were not easy to track. Figure 8 gives a first analysis of calculated front velocities between the front gauges of the various pairs of gauges. In the legend a sensor means the first wire gauge of a pair. Sensor 1 was placed just behind the crest on the inner slope. The other sensors were spaced $2.5 \mathrm{~m}$ down the slope. Sensor 1-3 gives the front velocity between sensors 1 and 3, the upper part of the slope. Sensor 79 gives the location near the toe of the inner slope. 
Figure 8 still shows quite some scatter, mainly due to errors in data processing, but the main trend is clear. At the crest (the triangles of sensors 1-3) small overtopping volumes give low velocities, which increase with increasing overtopping volumes. The trend is close to the theoretical prediction of Bosman et al. (2007). It is also clear that the velocity increases down the slope. Sensors 3-5 and 5-7 give increased velocities for all volumes. For small volumes, say lower than $1000 \mathrm{l} / \mathrm{m}$, velocities at the crest of 3 to $4 \mathrm{~m} / \mathrm{s}$ increase to 4 to $6 \mathrm{~m} / \mathrm{s}$ at the end of the slope. More analysis is required to come to final conclusions.

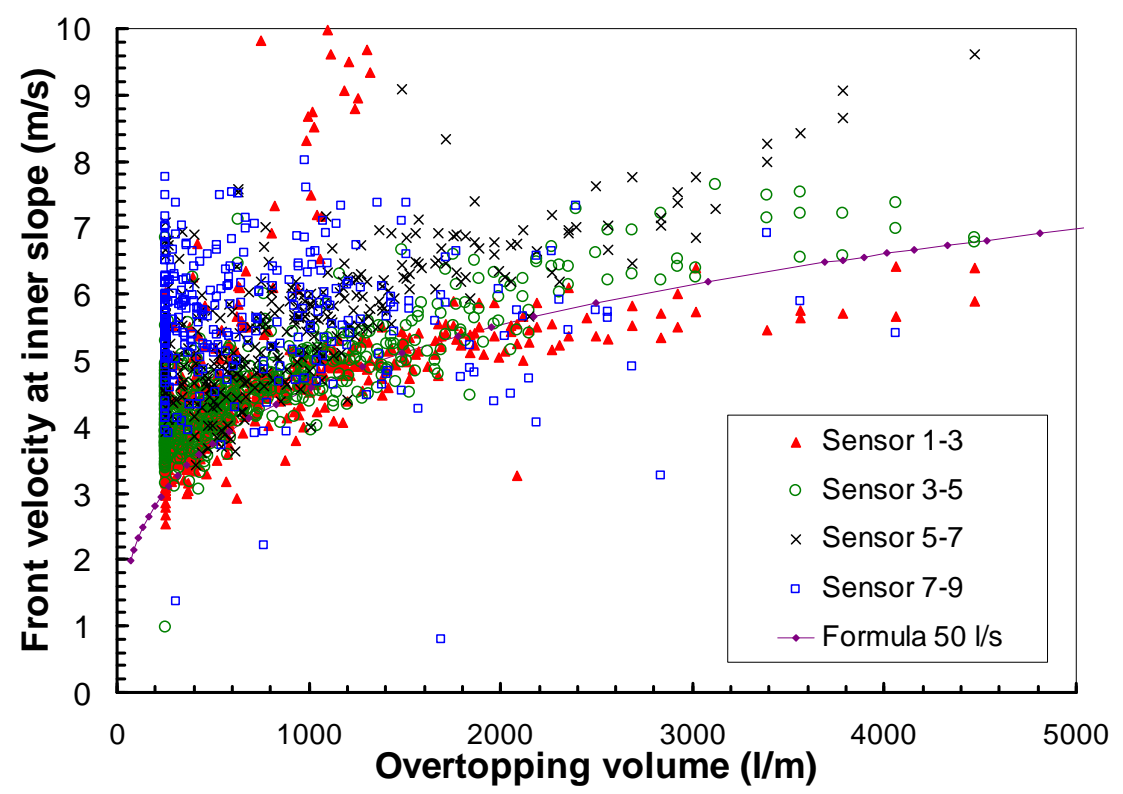

Figure 8. Measurements of front velocities of overtopping waves along the slope.

\section{DESTRUCTIVE FIELD TESTS}

\section{Failure mechansims}

Wave overtopping may lead to failure of the crest and inner slope of a dike. In principle there are two different failure mechanisms. Fast overtopping water may damage the surface of the crest and inner slope and, if initial damage or erosion has occurred, this may continue to the layer underneath the grass cover. This is actually the process which is simulated by the Wave Overtopping Simulator: erosion of the slope.

A major failure mechanism on steep inner faces (typically 1:1.5 and 1:2) in the past was slip failure of the (rear) slope. Such slip failures may lead directly to a breach. For this reason most dike designs in the Netherlands in the past fifty years have used a 1:3 inner slope, where it is unlikely that slip failures will occur due to overtopping. This mechanism might however occur for steep inner 
slopes, so should be taken into account in safety analysis. This failure mechanism is NOT simulated by the overtopping tests, as a slip failure needs more width to develop than the $4 \mathrm{~m}$ wide test section.

\section{Description of test locations}

Tests have been performed in 2007 and 2008, as described in the introduction section of this paper. Tests were performed in the winter season, when the grass condition is worst. A short description of the tested locations with some characteristics per location and per test is given below.

Delfzijl, Groningen (homogeneous clay dike)

Normal grass cover;

Reinforced grass cover (geotextile; Smart Grass Reinforcement - SGR); Bare clay (20 cm of grass cover removed).

Boonweg, Friesland (60 $\mathrm{cm}$ clay at inner slope on top of a sand core) Normal way of maintenance (grazing sheep, 4x per year);

2x grazing sheep, no fertilizer;

$1 \mathrm{x}$ grazing sheep, $1 \mathrm{x}$ mowing/hay, no fertilizer;

2x mowing/hay, no fertilizer, no grazing/sheep.

St Philipsland, Zeeland ( $60 \mathrm{~cm}$ clay on sand core)

$1 \mathrm{x}$ mowing/hay; steep inner slope $(1: 2,5)$, bad grass coverage.

Kattendijke, Zeeland (60 $\mathrm{cm}$ clay on sand)

$1 \mathrm{x}$ mowing/hay; bad grass coverage, many moles;

similar, damage by manure injector; 2 poles in the slope;

elastocoast (gravel and two-component glue);

open asphalt concrete.

\section{Limitations with respect to observations and conclusions}

Observations of the tests have led to preliminary conclusions, which are valid within the given boundary conditions for the tests, summarized as:

- only the failure mechanism of erosion of inner slopes by wave overtopping is considered (not sliding);

- the significant wave height considered in front of the dike should be around $2 \mathrm{~m}$;

- $\quad$ inner slopes should be between 1:2.5 and 1:3;

- the duration for an overtopping event (constant overtopping discharge) is 6 hours or less;

- grass cover to be comparable with Dutch situations (type of grass, winter season).

Observations and preliminary conclusions based on tests up to 2008

A tested inner slope of a dike, covered with grass, never failed by erosion due to overtopping for a mean overtopping discharge of $30 \mathrm{l} / \mathrm{s}$ per $\mathrm{m}$ or less. Only one section failed at $50 \mathrm{l} / \mathrm{s}$ per m; some at 75 l/s per m (see Figure 9), but part of the sections did not fail, even not for $75 \mathrm{l} / \mathrm{s}$ per m. 
It seems that the erosion resistance of the inner slope of a dike is determined most by the presence of grass and less by the erosion resistance (quality) of the clay. The variability of the grass sod has influence, but this may be less than previously anticipated. This could lead to the conclusion that the way of

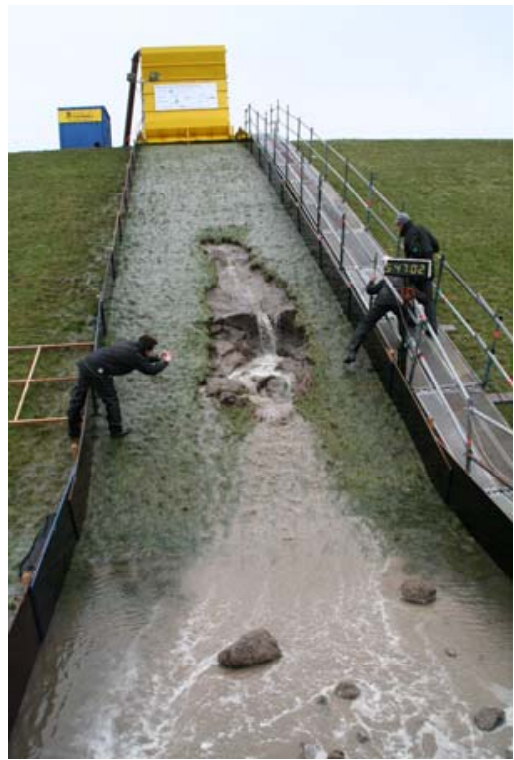

Figure 9. Erosion at inner slope for $75 \mathrm{l} / \mathrm{s}$ per overtopping maintenance of the grass has only minor effect on the strength of the inner slope.

Transitions from slope to horizontal are the most critical locations for initial and increasing damage. During the tests this was often the transition from the inner slope to the toe of the dike, with or without a maintenance road (see Fig. 10).

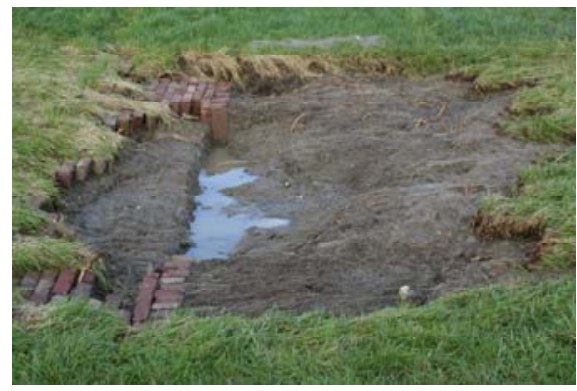

Figure 10. Damage at transition from slope to horizontal; $50 \mathrm{l} / \mathrm{s}$ per $\mathrm{m}$

Such damage was initiated by a mean discharge of $30 \mathrm{l} / \mathrm{s}$ per $\mathrm{m}$ or more. As the damage occurred at the lowest part of the inner slope it will take time for damage to extend to the crest level and subsequently to dike breach. Transitions higher on the inner slope (cycle paths, stability or piping berms with or without maintenance road, tracks of tractors, paths by sheep, roads crossing the dike, stairs), which have not yet been investigated, might be more critical.

A hole in the layer of clay, which reaches the under laying sand core and created at a large mean overtopping discharge of $50 \mathrm{l} / \mathrm{s}$ per $\mathrm{m}$ or more, will give a very quick ongoing erosion (see Figure 9). This has not been observed for smaller overtopping discharges, for the simple reason that these smaller discharges never created significant damage to the inner slope. Elastocoast and open asphalt concrete did not show any damage at 125 l/s per m, see Figure 11.

Small obstacles like poles did not show any erosion. Larger obstacles, like bigger poles, or a fence which exists already for a long time (with possibly many tracks of moles or mice in the long grass and different texture of the soil) have not been investigated, and may give rise to initiation of damage. Also here, further research may give more final conclusions. 
Some test sections showed the presents of (many) moles and sometimes mice. The tracks became clearly visible after first wave overtopping and sometimes the entrances eroded a little, but none of these natural damages gave initiation of damage to the inner slope.

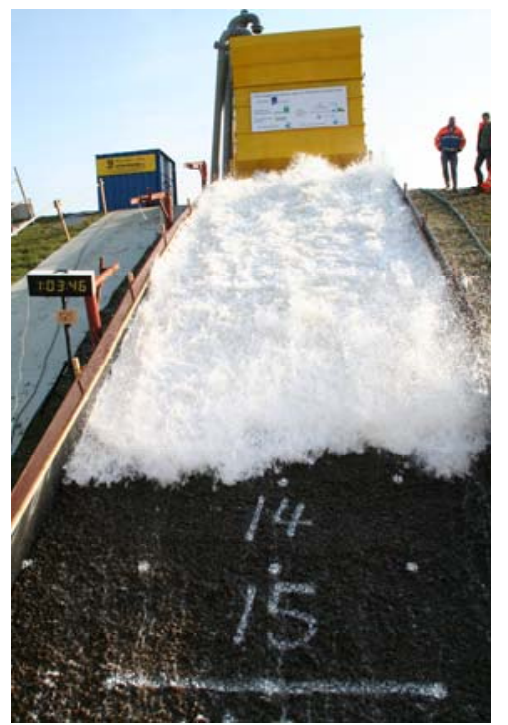

\section{SAFETY ASSESSMENT AND DESIGN}

Results of the testing show how strong the inner slope of a dike is for wave overtopping, what kind of failure mechanisms can be expected, what the week points are during overtopping and where further research should be focussed on.

It does, however, not describe how the results should be used in safety assessment of flood defence assets, nor in design of these assets.

For calculation of flood risk or probability of flooding it is required to have a good description of all failure mechanisms, up to the moment where a breach in the dike is initiated.

Figure 11. Elastocoast with $125 \mathrm{l} / \mathrm{s}$ per m

The design practice in the Netherlands over the past fifty years and more is that the required crest height is determined by almost no or little wave overtopping ( $\mathrm{l} / \mathrm{s}$ per $\mathrm{m}$ or a little more). The results of the tests show that there might be quite some extra strength or safety in the mechanism of erosion by wave overtopping. But it does not mean that the design philosophy should be changed, as it is required to have a safety margin in a proper design.

For safety assessment of erosion of inner slopes by wave overtopping, however, there might be a good reason to decide not to improve the height of the dike, if overtopping discharges are found to be a little larger than $1 \mathrm{l} / \mathrm{s}$ per $\mathrm{m}$. After further research it should be discussed if tolerable overtopping discharges for safety assessment should be increased and by how much. Above are only remarks on discussions that still have to be held and which eventually will lead to new guidance in design procedures, safety assessment procedures and flood risk assessments.

\section{ACKNOWLEDGMENTS}

ComCoast is acknowledged for their support to develop the Wave Overtopping Simulator and to perform the first tests in Groningen. The Ministry of Transport, Public Works and Water Management, the Centre for Water Management and the project group on Erosion by Wave Overtopping, including 
Deltares, Infram, Royal Haskoning and Alterra, are greatly acknowledged for recent overtopping tests at the Wadden Sea and the cooperation to come to early and preliminary conclusions on the test results. These tests were performed under the SBW-project (Strength and Loads on Water Defence Assets). Finally, the Project Organization of Sea Defences (Projectbureau Zeeweringen) of the Ministry is acknowledged for their support to perform the overtopping tests in the south west of the Netherlands.

\section{REFERENCES}

Akkerman, G.J., P. Bernardini, J.W. van der Meer, H. Verheij, A. van Hoven, 2007-1. Field tests on sea defences subject to wave overtopping. ASCE, proc. Coastal Structures CSt07, Venice, Italy.

Akkerman, G.J, K.A.J. van Gerven, H.A. Schaap and J.W. van der Meer, 2007-2. Wave overtopping erosion tests at Groningen sea dyke. ComCoast, Workpackage 3: Development of Alternative Overtopping-Resistant Sea Defences, phase 3. See www.comcoast.org.

Bosman, G., 2007. Velocity and flow depth variations during wave overtopping. MSc-thesis TU Delft.

Overtopping Manual, 2007. EurOtop; Wave Overtopping of Sea Defences and Related Structures - Assessment Manual. UK: N.W.H. Allsop, T. Pullen, T. Bruce. NL: J.W. van der Meer. DE: H. Schüttrumpf, A. Kortenhaus. www.overtopping-manual.com.

Steendam, G.J., W. de Vries, J.W. van der Meer, A. van Hoven, G. de Raat and J.Y. Frissel, 2008. Influence of management and maintenance on erosive impact of wave overtopping on grass covered slopes of dikes. Proc. FloodRisk, Oxford, UK.

Van der Meer, J.W., 2008. Erosion strength of inner slopes of dikes against wave overtopping. Preliminary conclusions after two years of testing with the Wave Overtopping Simulator. Summary Report.

Van der Meer, J.W., 2007. Design, construction, calibration and use of the wave overtopping simulator. ComCoast, Workpackage 3: Development of Alternative Overtopping-Resistant Sea Defences, phase 3. See www.comcoast.org.

Van der Meer, J.W., P. Bernardini, G.J. Akkerman and G.J.C.M. Hoffmans, 2007. The wave overtopping simulator in action. ASCE, proc Coastal Structures, Venice, Italy.

Van der Meer, J.W., W. Snijders and E. Regeling, 2006. The wave overtopping simulator. ASCE, proc. ICCE 2006, San Diego, 4654-4666. 
KEYWORDS - ICCE 2008

FURTHER DEVELOPMENTS ON THE WAVE OVERTOPPING SIMULATOR

Jentsje W. van der Meer, Gosse Jan Steendam, Govertine de Raat and Patricia Bernardini

Abstract number 190

Wave overtopping

Erosion

Destructive tests

Wave overtopping simulator

Dikes

Levees

Grass cover 